\title{
Biological and Molecular Characterization of Four Botryosphaeria Species Isolated from Pear Plants Showing Stem Wart and Stem Canker in China
}

Lifeng Zhai, College of Plant Science and Technology and National Key Laboratory of Agromicrobiology; Meixin Zhang, Gang Lv, Xiaoren Chen, and Nana Jia, College of Plant Science and Technology; and Ni Hong and Guoping Wang, College of Plant Science and Technology and National Key Laboratory of Agromicrobiology, Huazhong Agricultural University, Wuhan, Hubei 430070, China

\begin{abstract}
Zhai, L., Zhang, M., Lv, G., Chen, X., Jia, N., Hong, N., and Wang, G. 2014. Biological and molecular characterization of four Botryosphaeria species isolated from pear plants showing stem wart and stem canker in China. Plant Dis. 98:716-726.

Pear stem wart and pear stem canker, which have been considered as two different fungal diseases caused by pathogens belonging to Botryosphaeria spp., commonly occur and cause serious damage in the main pear-producing areas in China. To identify the species of this genus infecting pear in China, 131 Botryosphaeria isolates were recovered from pear samples exhibiting symptoms collected from 20 different provinces and areas. Morphological characterization and phylogenetic analyses of the ribosomal DNA internal transcribed spacer region and the $\beta$-tubulin and EF1- $\alpha$ genes revealed that Botryosphaeria dothidea, $B$. rhodina, $B$. obtusa, and $B$. parva were associated with different pear stem wart and stem canker symptoms. Remarkably, all isolates of $B$. dothidea were obtained from the samples showing either stem wart or stem canker lesions; however, the isolates of the other three species

were obtained only from the samples showing stem canker. Pathogenicity tests on the pear shoots showed that $B$. dothidea isolates could induce stem wart or stem canker lesions but all the isolates of the other three species could only induce stem cankers. However, the isolates of $B$. parva, B. rhodina, and B. obtusa exhibited higher virulence than that of the $B$. dothidea isolates on the pear fruit. Our results suggest that $B$. dothidea is the common causal agent for these two diseases (a pear stem wart and a pear-related stem canker), whereas $B$. parva, $B$. rhodina, and $B$. obtusa only cause pear stem canker diseases. To our knowledge, this study represents the first report for biological and molecular characterization of four Botryosphaeria spp. isolated from pear plants showing stem wart and stem canker in China.
\end{abstract}

Fruit ring rot, stem wart, and stem canker are important fungal diseases of apple and pear worldwide. These diseases have led to substantial economic losses due to excessive fruit rots or the severe suppression of tree growth $(1,5,19,53)$. In China, the fruit ring rot and stem wart diseases occur in almost all pear-growing areas. The stem canker disease, however, mainly occurs in northern China and only induces canker symptom on branches and trunks or twig dieback $(4,11)$. The symptom of the stem wart disease is characterized as small, rounded tuberculation ( 0.4 to $2.2 \mathrm{~mm}$ in diameter), with discoloration formed on the epidermis or periderm of the branch. However, the stem canker symptom mainly occurs on branches and shows black cankers and necrotic cortex. For a long time, pear stem wart and stem canker diseases have been considered as two diseases induced by fungi in the genus Botryosphaeria with differences in distribution and symptom (4).

To date, a number of Botryosphaeria spp. from diseased pear tissues have been identified $(5,39,44,53)$. In Japan, South Korea, and China, the pathogens causing pear fruit ring rot and stem wart diseases were considered to be Botryosphaeria berengeriana De Not and stem cankers were considered to be caused by $B$. berengeriana f. sp. piricola $(4,15,16)$. However, in many other pear-growing areas around the world, the fruit ring rot diseases were also called

Corresponding author: G. Wang, E-mail: gpwang @mail.hzau.edu.cn

* The $\boldsymbol{e}$-Xtra logo stands for "electronic extra" and indicates that two supplementary tables are available online.

Accepted for publication 9 January 2014.

http://dx.doi.org/10.1094/PDIS-10-13-1060-RE

(C) 2014 The American Phytopathological Society white rot disease, and its pathogen was considered to be $B$. dothidea (Moug.) Ces. \& De Not. (13,14,20,38). Some studies indicated that $B$. dothidea and $B$. berengeriana were synonyms because they had consistent molecular characteristics $(38,44)$. The fungus B. obtusa (Schwein.) Shoemaker is also found throughout most tropical and warm temperate regions in the world (8), and has been shown to be the causal agent of the frogeye leaf-spot, fruit black rot, and a limb canker of pear $(3,5)$ Some studies indicated that $B$. parva Pennycook \& Samuels and B. rhodina (Berk. \& M.A. Curtis) Arx were also associated with fruit rot, stem canker, and dieback on pear trees, with the former reported frequently in India $(9,34,35)$ and the latter in Europe and America $(19,22,36,39,53)$.

Because Botryosphaeria spp. rarely produce sexual structures under field and artificial culturing conditions, the identification and taxon of fungi in the genus has been mainly based on characteristics of pycnidium structures and conidia $(6,38)$. As more and more genomic sequences become available for phytopathogenic fungi, such as the internal transcribed spacer (ITS) region and $\beta$-tubulin, EF1- $\alpha$, and actin gene sequences, molecular data in combination with biological and morphological characteristics have been widely used for the discrimination of fungal species $(30,54)$.

Only recently have the pathogens causing stem wart and stem canker diseases of apple been identified (44). The results indicated that both stem wart and stem canker diseases in most apple-growing regions in China were caused by $B$. dothidea, which could induce stem wart under wet conditions and stem canker under drought conditions. However, the causal agents of pear stem wart and pear stem canker were rarely understood until now, despite the fact that the two diseases are widely present in China. This study was carried out to (i) accurately investigate causal agents of the stem wart and stem canker diseases of pear in China and (ii) determine the symptom types of pear diseases caused by those agents. 


\section{Materials and Methods}

Sources and isolation of fungi causing fruit ring rot, stem wart, and stem canker of pear. During 2010 to 2012, a field survey was carried out to determine the incidence of pear fruit ring rot, stem wart, and pear stem canker in the main pear-growing areas in 20 provinces in China (Fig. 1). To isolate the pathogens, pear tissues with characteristics of those diseases were collected. Typical concentric water-soaked ring lesions appeared on the surface of infected fruit (Fig. 2A and B). Infected leaves displayed concentric ring lesions, similar to those on infected fruit (Fig. 2C). The stem wart disease was characterized by infected lenticels that swelled and first formed warts (Fig. 2D), then necrotic tissues that formed saddle-shaped lesions (Fig. 2D). The stem canker disease mainly occurred on branches, where the infected stems initially showed a black canker (Fig. 2F); then, the lesion extended along the stem and, at last, the necrotic cortex cracked (Fig. 2G). In total, 140 diseased samples from pear trees (nearly 50 cultivars) were collected from pear orchards, of which 71 showed stem wart and 69 showed stem canker symptoms (Table 1). The sample tissues (each $5 \mathrm{~mm}$ long) taken from the border between the infected and uninfected areas were surface disinfected with $0.1 \%$ mercuric chloride for $1 \mathrm{~min}$ and $75 \%$ ethanol for $1 \mathrm{~min}$, rinsed with sterilized water twice, then air dried and placed on potato dextrose agar (PDA) plates. The plates were incubated at $25^{\circ} \mathrm{C}$ for 3 to 5 days. Fungal colonies showing features of Botryosphaeria spp. were transferred onto new PDA plates and incubated at $25^{\circ} \mathrm{C}$ for 36 to $48 \mathrm{~h}$. Six single-mycelium tips from the margin of each colony were individually picked up and subcultured onto PDA plates. One of six subcultures was recorded as one isolate and used for this study and the other five subcultures were stored in $25 \%$ glycerol at $-80^{\circ} \mathrm{C}$. In total, for this study, 131 isolates of Botryosphaeria spp. were analyzed and their cultural characteristics on PDA plates were examined after 3 days of incubation at $25^{\circ} \mathrm{C}$ in the dark. To induce the production of conidia, aerial mycelia of cultures were scratched with an inoculation needle and the plates were irradiated under near-UV light $(365 \mathrm{~nm})$. The morphological characteristics of the anamorphs, including size, shape, color, septation, wall thickness, and texture of conidia (2), were observed under a light microscope (Motic).

DNA extraction and polymerase chain reaction amplification of the ITS region and $\beta$-tubulin and EF1- $\alpha$ genes. Total DNA was extracted from each isolate by using the cetyltrimethylammonium bromide-based method, essentially as described by Sambrook and Russell (33), and the resulting DNA was subjected to polymerase chain reaction (PCR). The three primer sets listed in Supplementary Table 1 were used for the amplification of the fungal ITS region and $\beta$-tubulin and EF1- $\alpha$ genes $(10,12,48)$. PCR was performed in a $50-\mu \mathrm{l}$ volume containing 20 to $50 \mathrm{ng}$ of genomic DNA template, $0.2 \mu \mathrm{M}$ each primer, $0.25 \mu \mathrm{M}$ dNTPs, $5 \mu \mathrm{l}$ of $10 \mathrm{x}$ PCR buffer, and $4 \mathrm{U}$ of rTaq (TaKaRa Corporation). The PCR reaction condition was as follows: $94^{\circ} \mathrm{C}$ for $2 \mathrm{~min}$; followed by 35 cycles consisting of denaturation for $45 \mathrm{~s}$ at $94^{\circ} \mathrm{C}$, annealing for 45 $\mathrm{s}$ at $58^{\circ} \mathrm{C}$, and extension for $45 \mathrm{~s}$ at $72^{\circ} \mathrm{C}$; and final extension at $72^{\circ} \mathrm{C}$ for $10 \mathrm{~min}$. PCR was carried out in a 96-well block PCR Thermal Cycler (Model PTC-100; MJ Research). The amplified PCR products were gel-purified using MoreBio PCR Purification Kit (Wuhan More Biotechnology Corporation), and inserted into

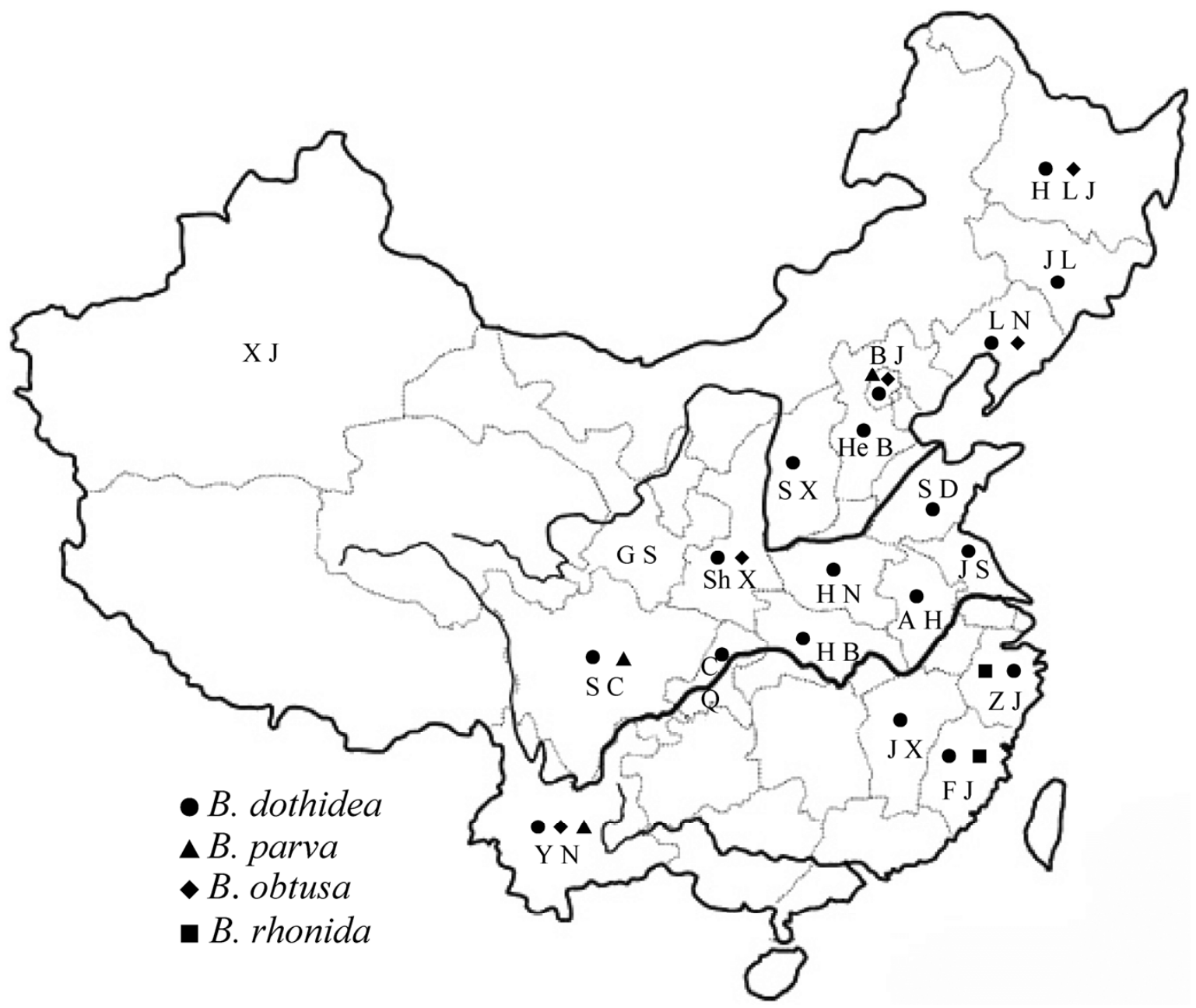

Fig. 1. Sample collections of pear ring rot and stem canker diseases and distribution of Botryosphaeriaceae species in China. Abbreviations indicate provinces or regions of Heilongjiang (HLJ), Jiling (JL), Liaoning(LN), Beijing City (BJ), Hebei (HeB), Shandong (SD), Shanxi (SX), Jiangsu (JS), Anhui(AH), Zhejiang (ZJ), Fujian (FJ), Hubei (HB), Jiangxi (JX), Sichuan (SC), Chongqing City (CQ), Yunnan (YN), Henan (HN), Shananxi (ShX), Gansu (GS), and Xinjiang (XJ). 
pMD18-T easy vector (TaKaRa Corporation). The recombined plasmids were transformed into Escherichia coli DH5 $\alpha$, and inserts were sequenced by Genscript Corp., and the obtained sequences were deposited into the GenBank database (Supplementary Table 2).

Phylogenetic analysis. Sequences were edited and assembled using DNAMAN (version 5.2.2; Lynnon Biosoft). The BLASTN program (http://blast.ncbi.nlm.nih.gov/Blast.cgi) was employed to search similar fungal sequences available in the GenBank database. Multiple sequence alignments were carried out by using CLUSTALX version 1.83. A phylogenetic tree was constructed by using the neighbor-joining method in the MEGA 4.0 software. The robustness of the inferred evolutionary relationships was assessed by 1,000 bootstrap replicates. ITS, $\beta$-tubulin, and EF1- $\alpha$ sequences of four isolates (CMW8000, CMW994, CMW7774, and CMW9074 representing B. dothidea, B. parva, B. obtusa, and B.
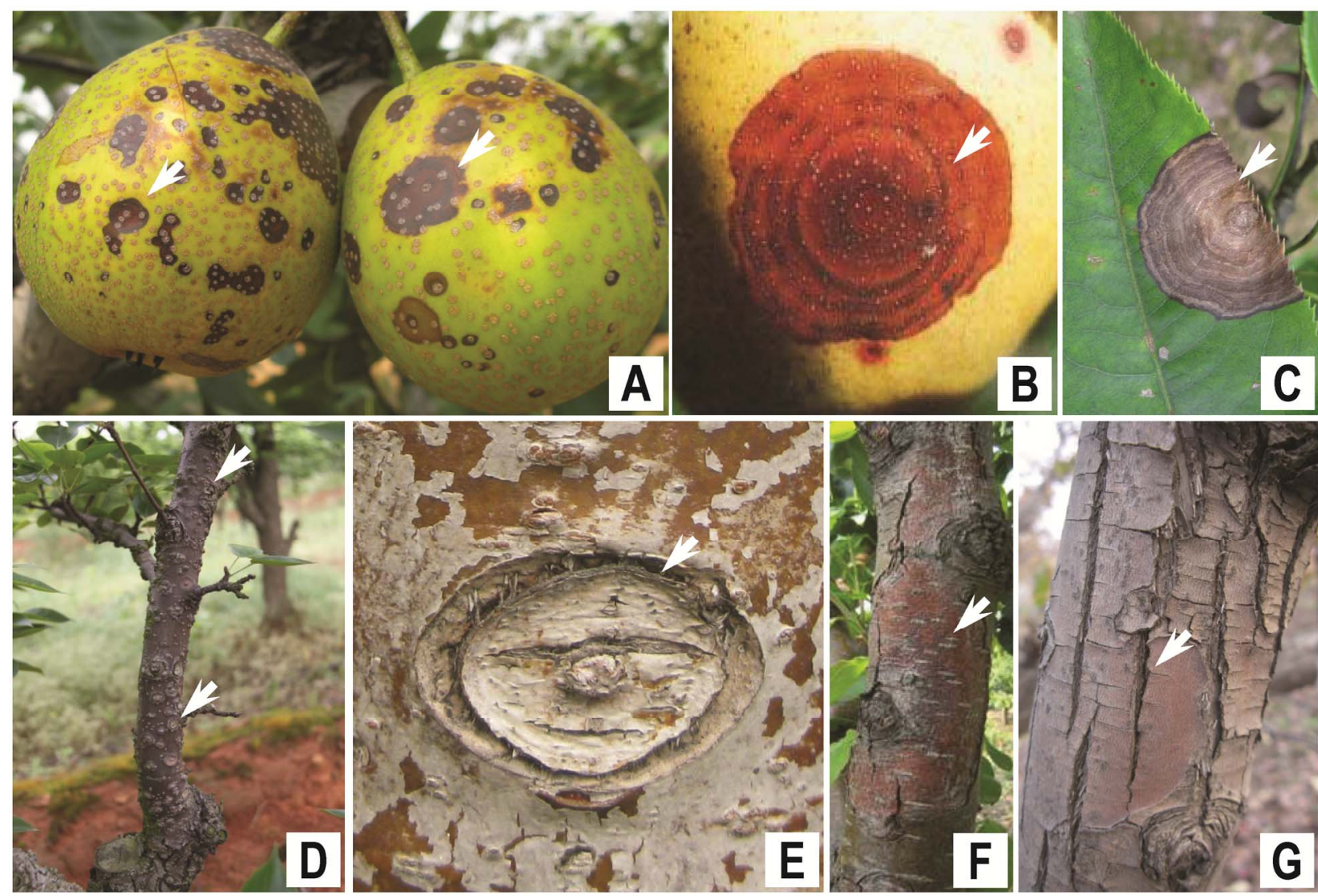

Fig. 2. Typical symptoms of pear ring rot and stem canker in the field. $\mathbf{A}$ and $\mathbf{D}$, Complex ring rot symptoms on fruit and stem, respectively; $\mathbf{B}$ and $\mathbf{C}$, single lesion showing ring rot on fruit and leaf, respectively; $\mathbf{D}$, wart symptoms of the initial ring rot on stem; $\mathbf{E}$, a close view of ring rot on stem with wart appearance; $\mathbf{F}$ and $\mathbf{G}$, initial and late symptoms of stem canker, respectively. All symptoms are indicated by arrows.

Table 1. Pathogenic isolates of Botryosphaeria spp. obtained from pear samples collected in different regions in China

\begin{tabular}{|c|c|c|c|c|c|c|c|c|}
\hline \multirow[b]{2}{*}{ Sample location } & \multirow[b]{2}{*}{$N^{\mathrm{c}}$} & \multicolumn{4}{|c|}{ Species identified $^{\mathrm{a}}$} & \multicolumn{3}{|c|}{ Sequences obtained from isolates ${ }^{b}$} \\
\hline & & Botryosphaeria dothidea & B. parva & B. rhodina & B. obtusa & ITS & $\beta$-Tubulin & EF1- $\alpha$ \\
\hline Beijing & 5 & 3 & 1 & $\ldots$ & 1 & 4 & 2 & 2 \\
\hline Chongqing & 1 & 1 & $\ldots$ & $\ldots$ & $\ldots$ & 1 & $\ldots$ & $\ldots$ \\
\hline Heilongiiang & 1 & ... & $\ldots$ & $\ldots$ & 1 & 1 & $\ldots$ & $\ldots$ \\
\hline Jiling & 4 & 4 & $\ldots$ & $\ldots$ & $\ldots$ & 3 & 1 & 1 \\
\hline Liaoning & 9 & 8 & $\ldots$ & $\ldots$ & 1 & 5 & $\ldots$ & $\ldots$ \\
\hline Hebei & 3 & 3 & $\ldots$ & $\ldots$ & $\ldots$ & 0 & 1 & 1 \\
\hline Shandong & 13 & 13 & $\ldots$ & $\ldots$ & $\ldots$ & 10 & 6 & 5 \\
\hline Jiangsu & 9 & 9 & $\ldots$ & $\ldots$ & $\ldots$ & 7 & 3 & 3 \\
\hline Zhejiang & 4 & 3 & $\ldots$ & 1 & $\ldots$ & 4 & 2 & 2 \\
\hline Shanxi & 5 & 5 & $\ldots$ & $\ldots$ & $\ldots$ & 3 & 1 & 1 \\
\hline Shaanxi & 5 & 4 & $\ldots$ & $\ldots$ & 1 & 4 & 3 & 3 \\
\hline Henan & 14 & 14 & $\ldots$ & $\ldots$ & $\ldots$ & 9 & 3 & 3 \\
\hline Hubei & 31 & 31 & $\ldots$ & $\ldots$ & $\ldots$ & 21 & 8 & 9 \\
\hline Anhui & 2 & 2 & $\ldots$ & $\ldots$ & $\ldots$ & 2 & 1 & $\ldots$ \\
\hline Jiangxi & 4 & 4 & $\ldots$ & $\ldots$ & $\ldots$ & 1 & $\ldots$ & $\ldots$ \\
\hline Fujian & 7 & 6 & $\ldots$ & 1 & $\ldots$ & 4 & 4 & 3 \\
\hline Yunnan & 10 & 3 & 5 & $\ldots$ & 2 & 10 & 7 & 8 \\
\hline Sichuan & 4 & 3 & 1 & $\ldots$ & $\ldots$ & 4 & $\ldots$ & 1 \\
\hline Total & 131 & 116 & 7 & 2 & 6 & 93 & 41 & 42 \\
\hline
\end{tabular}

${ }^{a}$ Numbers of isolates for each species from each province or region.

${ }^{\mathrm{b}}$ Numbers of internal transcribed spacer (ITS), $\beta$-tubulin, and EF1- $\alpha$ sequences.

${ }^{c}$ Total numbers of isolates from the indicated province or region. 
rhodina, respectively), were retrieved from the GenBank database and used as the reference in phylogenetic analysis.

Pathogenicity tests. Isolates of Botryosphaeria spp. showing different morphological and molecular characteristics were tested for their pathogenicity on attached or detached shoots and fruit of pear. All isolates were grown on PDA at $25^{\circ} \mathrm{C}$ for 3 days prior to inoculation. At least six shoots and four fruit were used for each inoculation experiment, and two independent experiments were carried out.

For the inoculation on intact plants, 1-year-old shoots on 3-yearold pear (Pyrus pyrifolia 'Hohsui') plants grown in a field were used. In total, 22 isolates, including 13 isolates of $B$. dothidea, 4 isolates of $B$. parva, 4 isolates of B. obtusa, and 1 isolate of $B$. rhodina, were tested for their pathogenicity on unwounded shoots by placing colonized agar plugs ( $5 \mathrm{~mm}$ in diameter) on the surface of lenticels directly. Sixteen isolates (eight $B$. dothidea, three $B$. parva, four $B$. obtusa, and one B. rhodina) were tested on wounded shoots. For the wounding treatment, intact shoots were disinfested with $75 \%$ ethanol and a wound $(0.2 \mathrm{~mm}$ in diameter) was made on each shoot with a sterilized needle $(0.25 \mathrm{~mm}$ in diameter $)$. A 5mm-diameter colonized agar plug was placed on top of the wounded sites of pear shoots. A PDA plug without the fungi was used as the noninoculated control. The inoculated sites were wrapped with plastic film strips to keep high humidity, and the film strips were removed at 10 days post inoculation (dpi). Symptom development was monitored and disease incidence was recorded every 10 days.

For inoculation on detached host tissues, 12 isolates $(5 \mathrm{~B}$. dothidea, 3 B. parva, 3 B. obtusa, and 1 B. rhodina) were tested on wounded 1-year-old shoots (10 cm in length) of pear (P. pyrifolia Hohsui) and mature fruit of pear (P. bretschneideri 'Huangguan'). The shoots and fruit were disinfested with $75 \%$ ethanol prior to the inoculation. One wound $(0.2 \mathrm{~mm}$ in diameter) was made on each shoot with a sterilized needle $(0.25 \mathrm{~mm}$ in diameter $)$. The $5-\mathrm{mm}-$ diameter colonized plug was placed on the wound. The inoculated sites of shoots and fruit were covered with sterilized moist cottonballs and incubated at $25^{\circ} \mathrm{C}$ in a plastic container, and the container was covered with plastic film. The cotton-balls were removed from inoculated shoots and fruit at $2 \mathrm{dpi}$ and $24 \mathrm{~h}$ post inoculation (hpi), respectively. The symptoms and disease incidences were recorded at $15 \mathrm{dpi}$ on shoots and the diameter of fruit lesion was recorded daily up to $10 \mathrm{dpi}$.

For each pathogenicity test on shoots, disease incidence was calculated as the percentage of the inoculation sites showing wart, lesion, or decay symptoms in each replicate.

Statistical analysis. Data from repeated tests and among treatments in each test were compared by using analysis of variance in SAS (version 9.0; SAS Institute). Means between treatments in each test were separated using the Fisher's least significant difference test at $P \leq 0.05$.

\section{Results}

Isolation and cultural characteristics of causal agents of pear stem wart and stem canker. In total, 131 isolates showing typical culture and conidial morphology of Botryosphaeria spp. on PDA plates were obtained from 140 samples, and those were isolated from 18 of 20 pear-growing regions (Table 1; Fig. 1). Other fungal species from genera such as Alternaria, Phomopsis, and Valsa isolated from diseased samples were not included in this study. Further comparisons on culture phenotypes on PDA plates at $25^{\circ} \mathrm{C}$ in darkness and morphological characteristics of conidia divided all these isolates into five groups.

In total, 88 isolates were classified into group 1. Their colonies, with short, thick, and solid aerial hyphae, were initially white and turned to dark after 5 days of incubation. The color viewed from the bottom side of the plates was at first white and gradually turned to deep green or dark (data not shown) at about $5 \mathrm{dpi}$. The conidia of this group of isolates were spindle or narrow fusiform, transparent, thin, and single cell (Fig. 3). Conidial size was 13.21 to 33.57 by 4.28 to $9.51 \mu \mathrm{m}$, with a mean length/width (L/W) ratio of 3.80
(Table 2). Group 2 included 28 isolates, and the colonies of this group were shallow gray in color and covered by abundant aerial hyphae with a ragged colony border (Fig. 3). The features of the bottom-side-view of culture plates were similar to group 1 . There were a few pycnidia formed on the surface of PDA plates after 15 days of incubation. The characteristics of conidia were like group 1 (Fig. 3), with sizes of 13.76 to 28.00 by 3.87 to $8.37 \mu \mathrm{m}$, and a mean L/W ratio of 3.51 (Table 2). Group 3 comprised only two isolates obtained from canker samples. The colony was white with abundant and erect aerial hyphae (Fig. 3). On the bottom side of culture plates, the entire colony was dark gray and black after 30 days of incubation. The conidia of the isolates in this group were oblong, straight, at first hyaline and aseptate, ultimately becoming

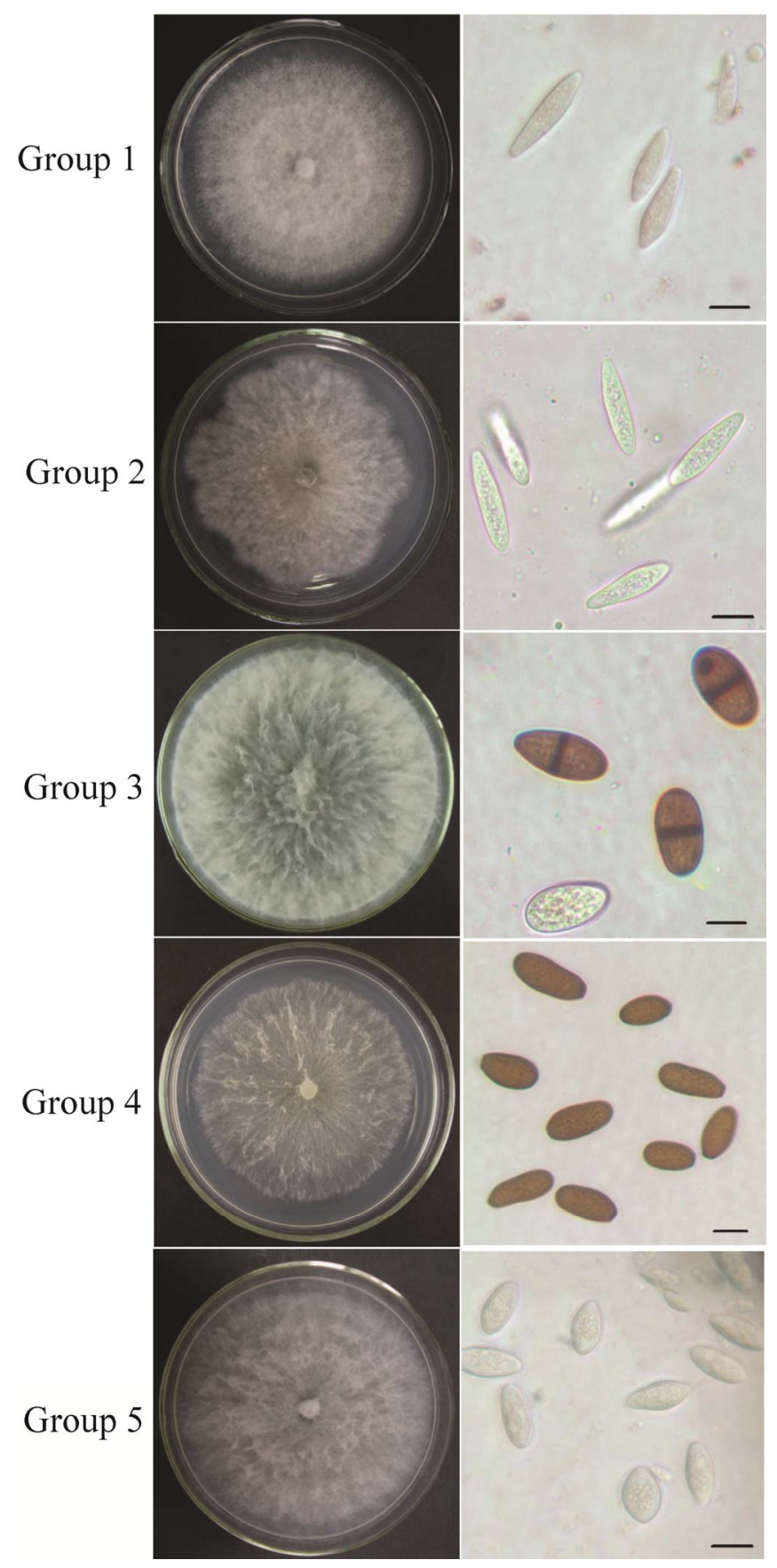

Fig. 3. Colonial and conidial morphologies of Botryosphaeria isolates. Photos showed representative morphologies of colonies and conidia of group 1 isolate (JNT1111) and group 2 isolate (ZH2211) of Botryosphaeria dothidea, group 3 isolate (ZHn411) of B. rhodina, group 4 isolate (DH411) of B. obtusa, and group 5 isolate (DL2611) of B. parva. All isolates were incubated on potato dextrose agar plates for 3 days at $25^{\circ} \mathrm{C}$ in continuous darkness. Scale bars $=10 \mu \mathrm{m}$. 
dark brown and one septate, with irregular longitudinal striations. These were broadly rounded at apex but truncate at base (Fig. 3). Conidial sizes were 17.12 to 31.7 by 11.41 to $18.45 \mu \mathrm{m}$, with an L/W ratio of 1.74 (Table 2). Group 4 had six isolates from canker samples. Colonies with white aerial hyphae sparsely and radially distributed on the PDA plate (Fig. 3) turned gray and dark. The conidia were oblong, brown, and aseptate with broadly round apex and truncate bases (Fig. 3). Conidial sizes were 12.10 to 26.27 by 6.63 to $14.70 \mu \mathrm{m}$, with a mean L/W ratio of 1.95 (Table 2). Group 5 had seven isolates from canker samples. Colonies were white and the aerial hyphae were upright and more rigid than the isolates of the other groups, except for the group 3 (Fig. 3). The bottom-sideviews of culture plates were slightly yellow or brownish. The entire colony was dark-gray and pycnidia arranged around the edges of PDA plates. Conidia were hyaline, aseptate, and ellipsoidal, with round apices and truncate bases (Fig. 3). Conidial sizes were 11.00 to 28.31 by 4.82 to $9.46 \mu \mathrm{m}$ (Table 2), with a mean $\mathrm{L} / \mathrm{W}$ ratio of 2.62 .

The colonial and conidial characteristics of groups 1, 3, 4, and 5 were similar to those of the typical isolates of $B$. dothidea (31), rhodina $(7,24,28)$, B. obtusa $(29)$, and $B$. parva $(25,37)$, respectively, as described on the Botryosphaeria website (http://www. crem.fct.unl.pt/botryosphaeria_site). The isolates of group 2 belonged to a species in the genus Botryosphaeria based on the characteristics of their colonies and conidia.

Molecular phylogenetic analysis of isolates. Fragments of the ITS region and $\beta$-tubulin and EF1- $\alpha$ genes were amplified from 93, 41 , and 42 isolates, respectively (Table 1 ). The sizes of ITS, $\beta$ tubulin, and EF1- $\alpha$ PCR amplicons of these isolates were 542 to 586, 458 to 461 , and 286 to 316 bp in length, respectively. Multiple sequence alignments showed that all of these isolates shared 95.6 to $100,97.1$ to 100 , and 87.8 to $100 \%$ nucleotide identities for the ITS fragment and $\beta$-tubulin and EF1- $\alpha$ genes, respectively.

The phylogenetic analysis results of ITS sequences showed that 93 isolates were clustered into four clades (Fig. 4). The 77 isolates in the morphological group 1 and group 2, together with a representing isolate of $B$. dothidea CMW8000 from Switzerland, formed clade 1 in the phylogenetic tree. The other two, six, and seven isolates in morphological groups 3, 4, and 5 formed three clades, together with isolates represented by $B$. rhodina from Mexico, B. obtusa from the United States, and B. parva from New Zealand, respectively (Fig. 4). When ITS sequences combined with $\beta$ tubulin and EF1- $\alpha$ sequences were employed for the phylogenetic analysis, similar phylogenetic relationships were inferred (Fig. 5). These results indicated that all isolates from pear wart and stem canker diseased tissues could be identified as four species- $B$. dothidea, B. parva, B. obtusa, and B. rhodina-in view of their morphological characteristics and molecular phylogrouping relationships.

Pathogenicity comparison of four Botryosphaeria spp. The wart symptoms were commonly visible on pear shoots of intact plants at 40 to $60 \mathrm{dpi}$ with colonized plugs of $B$. dothidea isolates, including isolates from groups 1 and 2 (except on wounded shoot; Figs. 6 and 7). However, wart symptoms did not develop further during the observation period of this study. Stem cankers were characterized as flaky, necrotic lesions with discoloration of cortex tissue on pear shoots observed about 15 dpi. In this study, cankers were induced upon inoculation on unwounded pear shoots of intact plants with colonized plugs of $B$. dothidea isolates; all canker lesions expanded within 60 dpi but only a few caused the dieback of the entire shoot. At $40 \mathrm{dpi}$, there were significant differences $(P<$ 0 . 01) in disease incidence caused by the tested isolates of this species, and disease incidence ranged from 8.3 to $77.8 \%$ (Table 3). The disease incidences caused by group 1 and group 2 isolates showed similar levels of variation. All tested isolates of this species induced the black canker lesions on wounded, detached shoots and wounded shoots of intact plants. When wounded shoots were inoculated with colonized plugs of $B$. dothidea isolates, there were also significant differences $(P<0.01)$ in the disease incidences caused by the tested isolates, which were 41.7 to $75.0 \%$ on wounded shoots of intact plants at $40 \mathrm{dpi}$ and 20.8 to $68.8 \%$ on wounded detached shoots at $15 \mathrm{dpi}$. For pathogenicity tests of isolates of this species on wounded pear fruit, all $B$. dothidea isolates induced small necrotic spots at $24 \mathrm{hpi}$ and the rot tissue quickly expended into all fruit at approximately $10 \mathrm{dpi}$. The diameter of lesions was 12.8 to $19.9 \mathrm{~mm}$ and differed significantly $(P<0.01)$ among the isolates at 3 dpi (Table 3; Fig 8).

In contrast to $B$. dothidea, $B$. parva only induced brown-dark cankers on shoots (Fig. 6). The canker expanded quickly, separated from the healthy tissues, and developed a depressed area at $20 \mathrm{dpi}$. On unwounded stems of intact pear plants, those tested $B$. parva isolates caused significantly different $(P<0.01)$ disease incidences of 13.3 to $77.8 \%$ at $40 \mathrm{dpi}$. On wounded shoots of intact plants, the brown canker lesions often appeared (Fig. 7). On detached shoots, the infection of $B$. parva caused necrotic lesions at 24 to 36 hpi. The length of lesions was significant greater than that caused by $B$. dothidea (data not shown) and the disease incidences caused by isolates of this species reached $100 \%$, except for isolate DJ2321, which caused $85.7 \%$ disease incidence on detached shoots. On inoculated fruit, small necrotic spots developed at 12 to $24 \mathrm{hpi}$, and the necrotic lesions quickly expended and resulted in fruit rot within 5 dpi. The diameters of lesions were 20.2 to $29.5 \mathrm{~mm}$,

Table 2. Conidial dimensions of Botryosphaeria spp. isolates that caused pear ring rot and canker from China

\begin{tabular}{|c|c|c|c|}
\hline \multirow[b]{2}{*}{ Isolates } & \multicolumn{3}{|c|}{ Conidial dimensions } \\
\hline & Conidial size ranges $(\mu \mathrm{m})^{\mathrm{a}}$ & Mean \pm SD $(\mu \mathrm{m})^{b}$ & $\mathbf{L} / \mathbf{W}^{\mathrm{c}}$ \\
\hline \multicolumn{4}{|c|}{ Botryosphaeria dothidea } \\
\hline JNT1111 & $19.53-33.57 \times 5.71-9.51$ & $28.07 \pm 2.57 \times 7.58 \pm 0.85$ & $3.75 \pm 0.57$ \\
\hline YZZ1911 & $13.24-23.23 \times 4.42-8.40$ & $18.36 \pm 2.24 \times 6.16 \pm 0.99$ & $3.04 \pm 0.53$ \\
\hline ZH2211 & $15.14-25.59 \times 4.01-7.19$ & $21.68 \pm 2.09 \times 5.69 \pm 0.65$ & $3.86 \pm 0.59$ \\
\hline ZH3311 & $13.76-23.13 \times 3.87-7.21$ & $18.10 \pm 2.64 \times 5.57 \pm 0.84$ & $3.31 \pm 0.69$ \\
\hline YZN1311 & $14.32-28.00 \times 4.38-8.30$ & $20.97 \pm 2.85 \times 6.38 \pm 0.85$ & $3.35 \pm 0.64$ \\
\hline \multicolumn{4}{|l|}{ B. parva } \\
\hline DL2411 & $11.26-16.85 \times 5.11-8.38$ & $14.31 \pm 1.35 \times 6.62 \pm 0.71$ & $2.19 \pm 0.34$ \\
\hline DJ2311 & $15.95-28.31 \times 4.82-8.54$ & $22.97 \pm 2.57 \times 6.60 \pm 0.92$ & $3.55 \pm 0.62$ \\
\hline CL1411 & $11.00-20.04 \times 5.92-9.46$ & $16.70 \pm 2.14 \times 7.94 \pm 0.82$ & $2.13 \pm 0.38$ \\
\hline \multicolumn{4}{|l|}{ B. obtusa } \\
\hline J5211 & $12.10-26.67 \times 8.02-14.61$ & $20.54 \pm 2.70 \times 11.26 \pm 1.30$ & $1.85 \pm 0.32$ \\
\hline LSA3111 & $12.64-25.94 \times 6.63-12.37$ & $20.50 \pm 2.69 \times 9.67 \pm 1.35$ & $2.15 \pm 0.36$ \\
\hline DA221 & $13.67-24.12 \times 6.98-12.51$ & $18.98 \pm 2.45 \times 9.40 \pm 1.27$ & $2.05 \pm 0.32$ \\
\hline DA411 & $14.77-24.04 \times 9.1-14.07$ & $20.16 \pm 1.99 \times 11.56 \pm 1.17$ & $1.76 \pm 0.24$ \\
\hline \multicolumn{4}{|l|}{ B. rhodina } \\
\hline $\mathrm{ZHn} 411$ & $17.12-31.7 \times 11.41-18.45$ & $25.79 \pm 2.62 \times 14.95 \pm 1.56$ & $1.74 \pm 0.20$ \\
\hline
\end{tabular}

${ }^{a}$ Minimum and maximum size for length and width of 50 conidia were recorded from each selected Botryosphaeria isolate from China.

${ }^{\mathrm{b}} \mathrm{SD}=$ standard deviation.

${ }^{c}$ Length/width ratio. 
showed significant $(P<0.01)$ differences among the isolates of this species, and were larger than those caused by $B$. dothidea at 3 dpi (Table 3; Fig 8).

All the isolates of $B$. rhodina and B. obtusa did not cause any symptoms on unwounded shoots of intact pear plants but induced canker symptoms on wounded shoots of intact plants (Figs. 6 and 7). The disease incidence caused by isolate $\mathrm{ZHn} 411$ was up to
$100 \%$ (Table 3). On detached shoots, those inoculated with $B$. rhodina showed necrosis symptoms at $24 \mathrm{hpi}$; however, those inoculated with $B$. dothidea and $B$. obtusa showed necrosis at 5 dpi (data not shown). All tested isolates of B. obtusa infected detached, wounded shoots and showed levels of virulence on fruit similar to those of isolates of $B$. parva and B. rhodina (Table 3; Fig. 8).

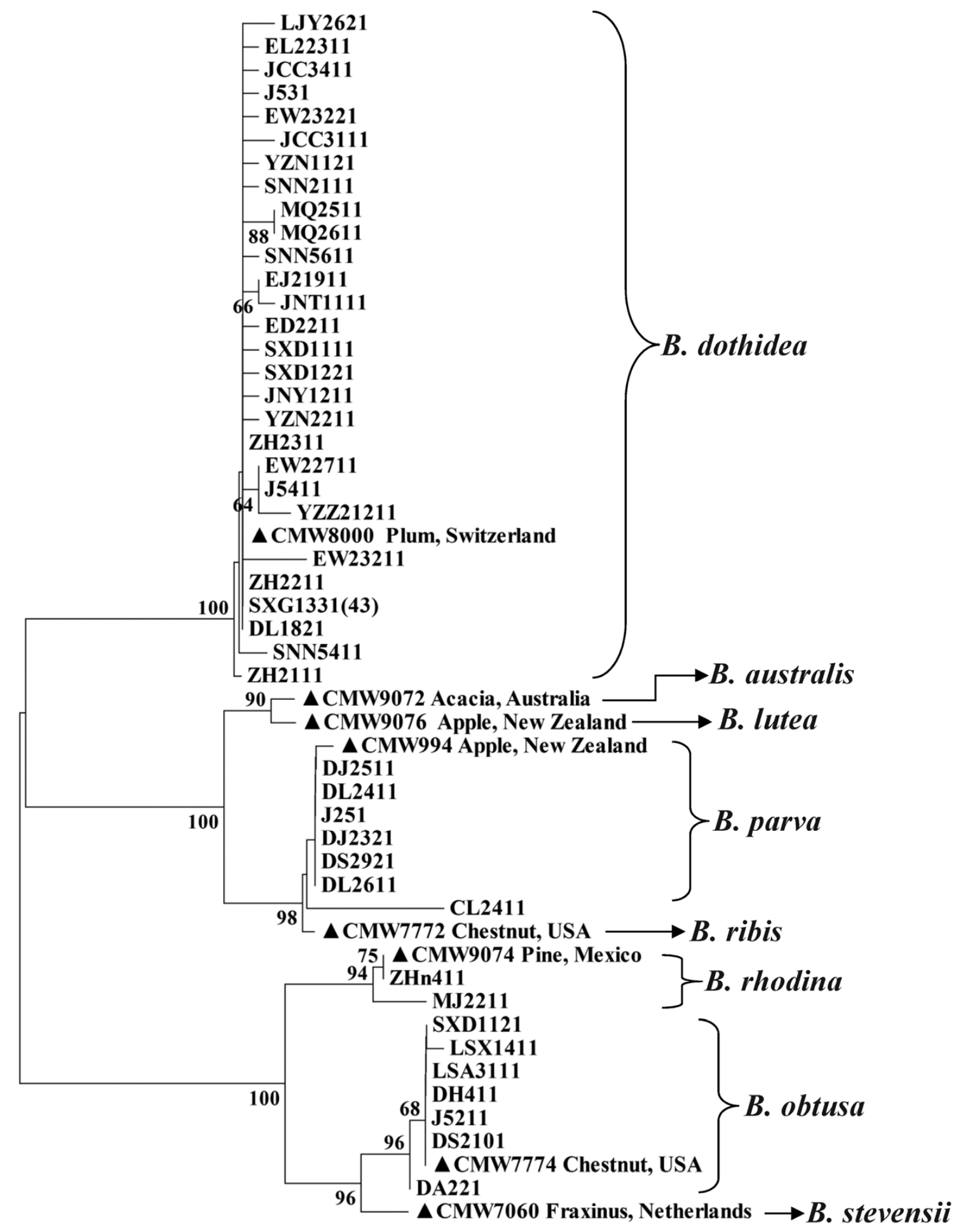

0.01

Fig. 4. Neighbor-joining phylogenetic analysis of Botryosphaeriaceae species isolated from diseased pear plants in China based on the ribosomal DNA internal transcribed spacer (ITS) sequences. Heuristic search with bootstrap value of 1,000 replications. Only $\geq 60 \%$ bootstrap values are shown, and branch lengths are proportional to the genetic distances. The same ITS sequences from different isolates having 100\% similarity were represented by one sequence (SXG1331) and their numbers are indicated in bracket. Reported ITS sequences from different isolates available in GenBank are indicated by a triangle $(\boldsymbol{\Delta})$. Distance scale $=0.01$. 
In summary, pathogenicity tests revealed that all isolates of $B$. dothidea induced stem wart and stem canker symptoms, except for the isolates of group 2 that failed to induce stem wart on wounded shoots, whereas all isolates of $B$. parva induced only stem canker but not stem wart on unwounded shoots of intact pear plants. All isolates of B. dothidea, B. parva, B. rhodina, and B. obtusa caused cankers on wounded shoots and rot on wounded pear fruit, suggesting that all Botryosphaeria isolates tested are pathogenic on pear. On the wounded fruit, lesion diameters induced by isolates of $B$. parva, $B$. rhodina, and $B$. obtusa were larger than those caused by isolates of $B$. dothidea (Table 3; Fig 8), indicating that virulence of $B$. parva, $B$. rhodina, and $B$. obtusa isolates was stronger than that of $B$. dothidea. In all the tests above, the control shoots and fruit did not show any symptoms. Pathogens were reisolated from the infected tissues of the inoculated shoots and fruit and confirmed to be the original isolates used for the inoculations. Based on our results, we conclude that $B$. dothidea was the main causal agent for both pear stem wart and pear stem canker and is widely distributed in pear-growing regions in China, whereas B. parva, B. rhodina, and $B$. obtusa only caused pear stem canker and occurred in some regions.

\section{Discussion}

This study represents the first attempt to characterize the species of Botryosphaeria associated with pear stem wart and stem canker in China, using integration of morphological, pathological, and molecular data. We have shown that four Botryosphaeria spp., identified as B. dothidea, B. parva, B. obtusa, and B. rhodina, are the causal agents of pear stem wart and stem canker diseases. In this study, all 131 isolates were initially divided into five groups

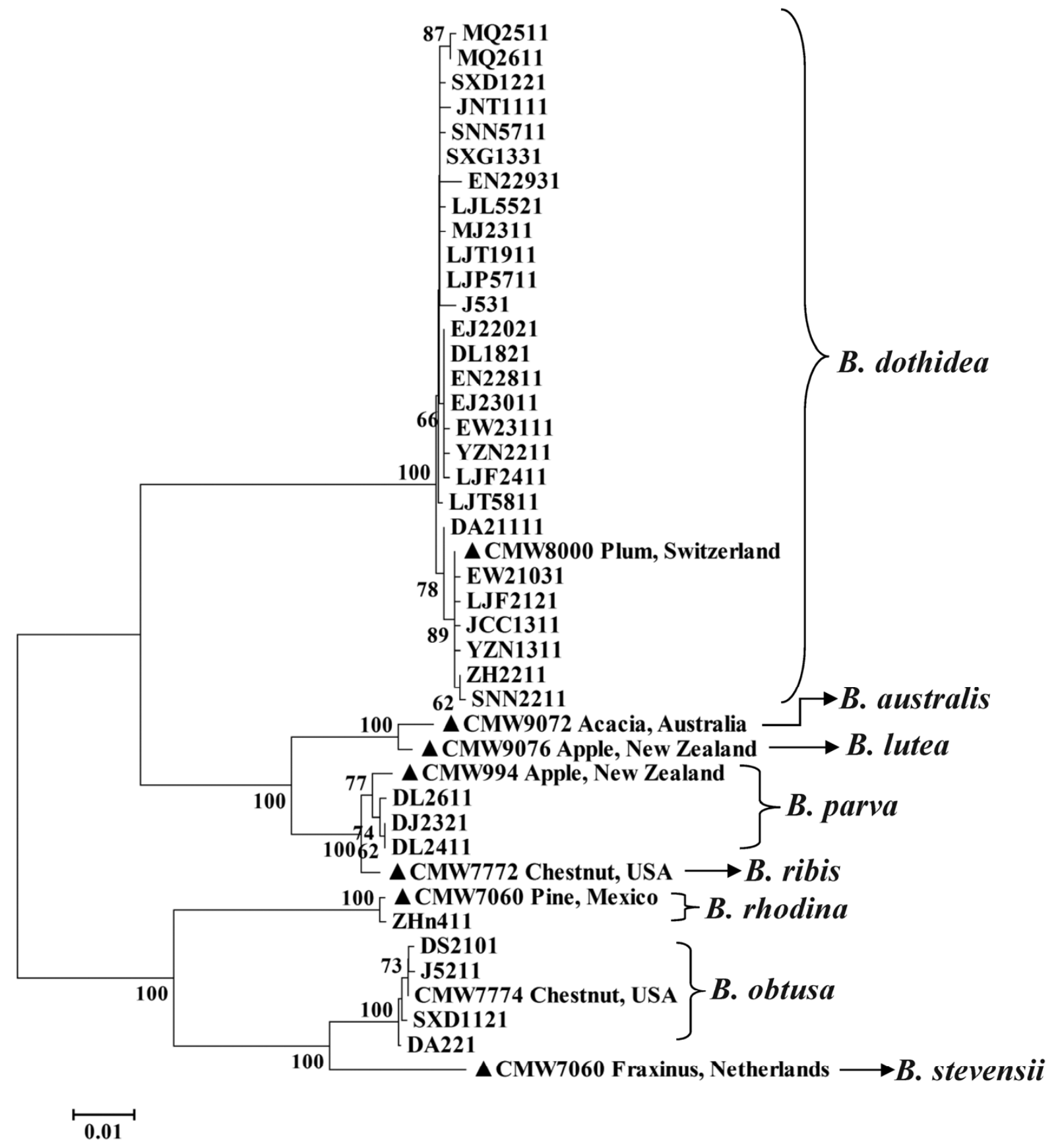

Fig. 5. Phylogenetic tree of Botryosphaeriaceae species associated with pear ring rot and stem canker in China using neighbor-joining analysis of combined internal transcribed spacer (ITS), $\beta$-tubulin, and EF1- $\alpha$ nucleotide sequences. Heuristic search with bootstrap value of 1,000 replications. Only $\geq 60 \%$ bootstrap values are shown, and branch lengths are proportional to the genetic distances. Reported ITS, $\beta$-tubulin, and EF1- $\alpha$ sequences from different isolates available in GenBank are indicated by a triangle $(\mathbf{\Delta})$. Distance scale $=0.01$. 
based on culture and conidial characteristics. Phylogenetic analyses of the ITS, $\beta$-tubulin, and EF1- $\alpha$ sequences further demonstrated that isolates belonging to one to five morphological groups were clustered into four Botryosphaeria spp. The morphological characteristics of group 2 isolates differ greatly from group 1 isolates but both groups belong to the same species of $B$. dothidea, based on comparison of sequence data. Other studies suggested that colony characteristics of Botryosphaeria isolates can be influ- enced by cultural conditions such as culture media and growth temperatures $(27,38)$. Moreover, species identifications based on conidial characteristics are also problematic because of large variations of the conidial morphology within the same species and the considerable similarity across different species of the genus (46). Therefore, systematic classification and identification of the Botryosphaeria spp. has been a great challenge. However, it is increasingly accepted that molecular sequence analyses (ribosomal DNA

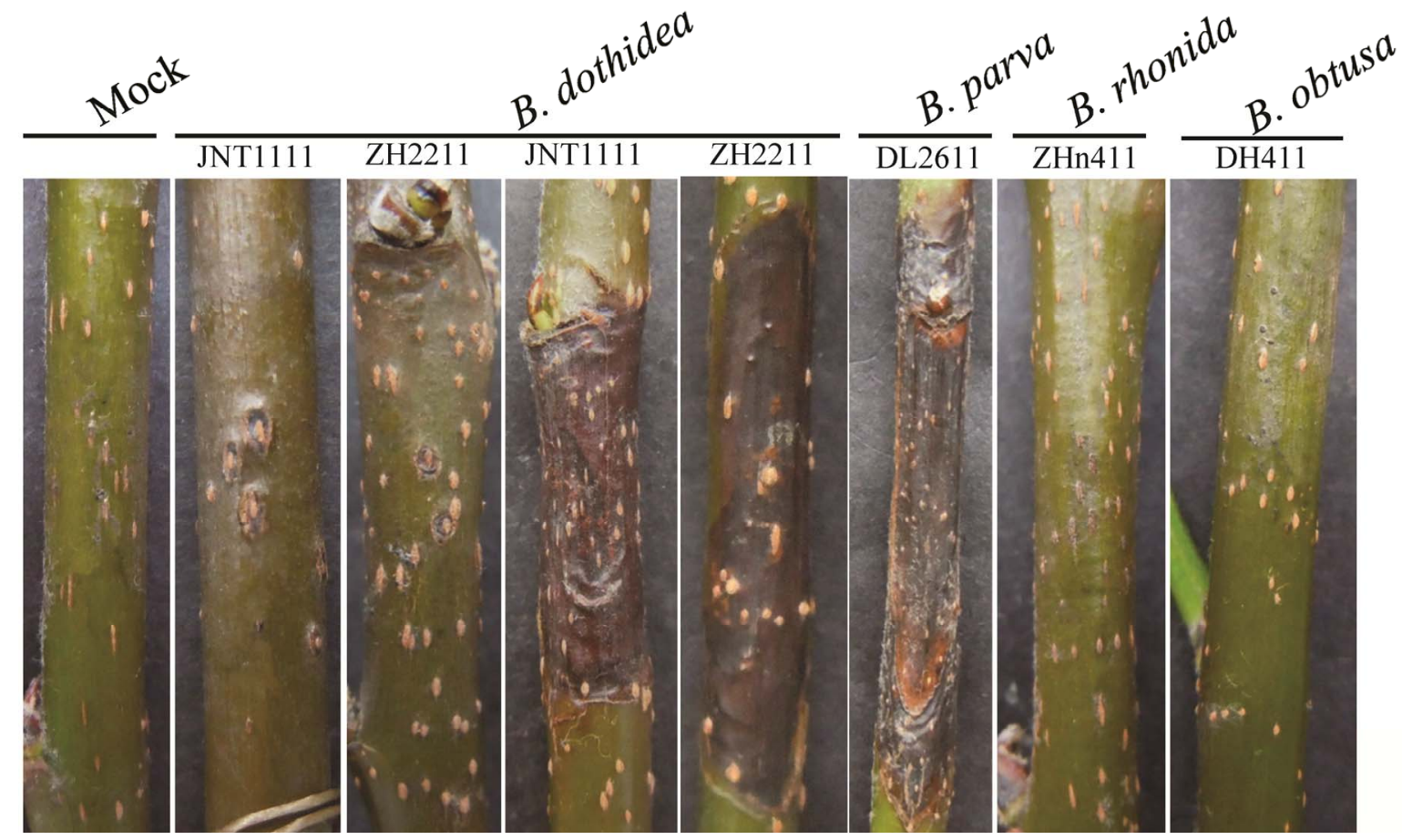

Fig. 6. Unwounded pear shoots (Pyrus pyrifolia 'Hohsui') were inoculated with colonized plugs and photographed at 40 days post inoculation. From left to right: mock-control with the fungus-free potato dextrose agar plugs, ring rot symptoms caused by Botryosphaeria dothidea (isolates JNT1111 and ZH2211), canker symptoms caused by B. dothidea (isolates JNT1111 and ZH2211), canker symptoms caused by B. parva (isolate DL2611), and symptomless upon inoculation with B. rhodina (isolate ZHn411) and B. obtusa (isolate DH411).

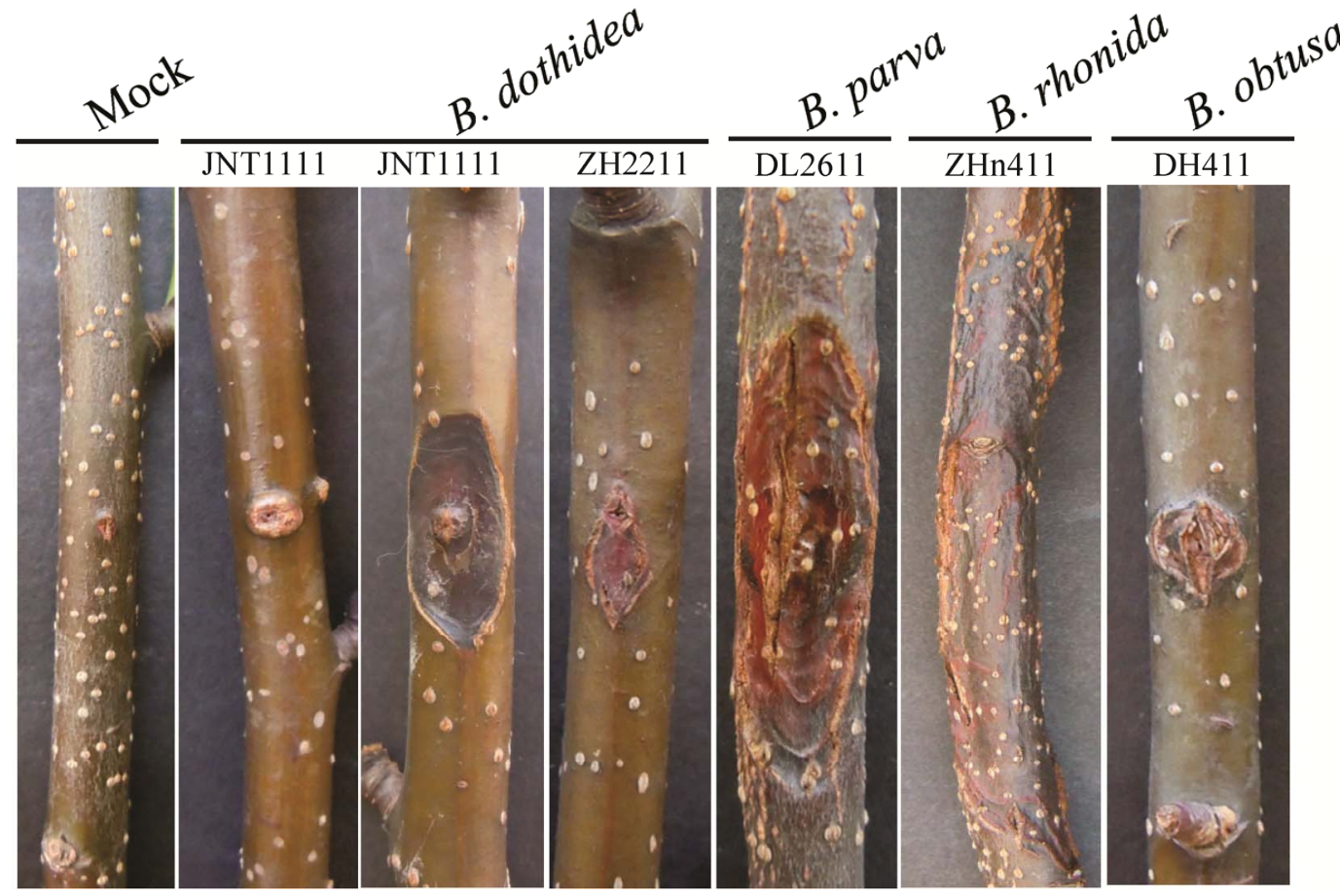

Fig. 7. Wounded pear shoots (Pyrus pyrifolia 'Hohsui') were inoculated with colonized plugs and photographed at 40 days post inoculation. From left to right: mock-control with the fungus-free potato dextrose agar plugs, ring rot symptom caused by Botryosphaeria dothidea (isolates JNT1111), canker symptoms caused by $B$. dothidea (isolates JNT1111 and ZH2211), B. parva (isolate DL2611), B. rhodina (isolate ZHn411), and B. obtusa (isolate DH411). 
ITS, $\beta$-tubulin, EF1- $\alpha$, and actin) and DNA labeling methods (random amplified polymorphic DNA, intersimple- or short-sequence repeat, and simple-sequence repeat) should be used to confirm or clarify the taxonomy of the genus species $(21,26,31,54)$.

Distribution and occurrence of Botryosphaeria spp. are worldwide. Thus far, numerous pathogenic isolates of this genus have been identified from many deciduous fruit and wood trees, including pear $(24,30)$, apple (44), peach (45), actinidia (27), grapevine (51), pistachio (42), blackberry (41), olive (17,32), mango (23), and eucalypt (43). Results of this study indicated that stem wart and stem canker diseases of pear occurring in most pear-growing regions in China were primarily caused by $B$. dothidea, which was

Table 3. Disease incidences and symptoms on pear shoots and fruit inoculated with isolates of Botryosphaeria spp. ${ }^{\text {a }}$

\begin{tabular}{|c|c|c|c|c|c|}
\hline \multirow[b]{3}{*}{ Species, isolates } & \multirow[b]{3}{*}{ Symptoms ${ }^{d}$} & \multirow{2}{*}{\multicolumn{2}{|c|}{$\frac{\text { Incidence }(\%)}{\text { Shoots of intact plants }^{b}}$}} & \multicolumn{2}{|c|}{ Lesion diameter (mm) } \\
\hline & & & & \multirow{2}{*}{$\frac{\text { Detached shoots }^{\text {b }}}{\text { Wounded }}$} & \multirow{2}{*}{$\begin{array}{c}\text { Fruit }^{c} \\
\text { Wounded }\end{array}$} \\
\hline & & Unwounded & Wounded & & \\
\hline \multicolumn{6}{|c|}{ Botryosphaeria dothidea } \\
\hline \multicolumn{6}{|c|}{ Group 1} \\
\hline LNT1111 & Wart or canker & $56.7 \pm 26.7$ & $58.3 \pm 8.3$ & $20.83 \pm 4.17$ & $19.9 \pm 1.0$ \\
\hline EL22111 & Wart or canker & $77.8 \pm 11.1$ & $75.0 \pm 25.0$ & $68.75 \pm 6.25$ & $14.3 \pm 1.7$ \\
\hline LJG2211 & Wart or canker & $75.0 \pm 25.0$ & - & $54.17 \pm 4.17$ & $12.8 \pm 1.4$ \\
\hline SNN2211 & Wart or canker & $19.4 \pm 2.8$ & $58.3 \pm 41.7$ & - & - \\
\hline YZZ3111 & Wart or canker & $26.7 \pm 6.7$ & $58.3 \pm 41.7$ & - & - \\
\hline LJL5511 & Wart & $56.7 \pm 26.7$ & $41.7 \pm 25$ & & \\
\hline YZZ11411 & Wart or canker & $66.7 \pm 16.7$ & - & - & - \\
\hline EL22411 & Wart or canker & $56.7 \pm 26.7$ & - & - & - \\
\hline MD2111 & Wart or canker & $56.7 \pm 26.7$ & - & - & - \\
\hline YZZ1911 & Wart or canker & $8.3 \pm 8.3$ & - & - & - \\
\hline \multicolumn{6}{|l|}{ Group 2} \\
\hline $\mathrm{ZH} 2311$ & Wart or canker & $35.0 \pm 15.0$ & $58.3 \pm 8.3$ & $58.33 \pm 8.34$ & $13.8 \pm 2.8$ \\
\hline ZH2211 & Wart or canker & $35.0 \pm 15.0$ & $75.0 \pm 8.3$ & $66.67 \pm 8.34$ & $14.8 \pm 2.2$ \\
\hline EJ23011 & Wart or canker & $40.0 \pm 10.0$ & $41.7 \pm 41.7$ & - & - \\
\hline \multicolumn{6}{|l|}{ B. parva } \\
\hline \multicolumn{6}{|l|}{ Group 3} \\
\hline DJ2321 & Canker & $13.3 \pm 3.3$ & $100.0 \pm 0.0$ & $85.71 \pm 14.29$ & $25.4 \pm 0.8$ \\
\hline DL2411 & Canker & $36.7 \pm 3.3$ & $100.0 \pm 0.0$ & $100 \pm 0$ & $29.5 \pm 1.1$ \\
\hline DL2611 & Canker & $40 \pm 10.0$ & $100.0 \pm 0.0$ & $100 \pm 0$ & $20.2 \pm 0.5$ \\
\hline DS2921 & Canker & $77.8 \pm 11.1$ & - & - & - \\
\hline \multicolumn{6}{|l|}{ B. obtusa } \\
\hline \multicolumn{6}{|l|}{ Group 4} \\
\hline DH411 & NS & $0.0 \pm 0.0$ & $30.0 \pm 2.0$ & $64.58 \pm 2.09$ & $19.9 \pm 2.2$ \\
\hline DA221 & NS & $0.0 \pm 0.0$ & $0.0 \pm 0.0$ & $37.5 \pm 12.5$ & $21.5 \pm 2.1$ \\
\hline LSA3111 & NS & $0.0 \pm 0.0$ & $0.0 \pm 0.0$ & $39.58 \pm 2.09$ & $19.6 \pm 0.9$ \\
\hline DS2101 & NS & $0.0 \pm 0.0$ & $50.8 \pm 20.2$ & - & - \\
\hline \multicolumn{6}{|l|}{ B. rhodina } \\
\hline \multicolumn{6}{|l|}{ Group 5} \\
\hline ZHn411 & NS & $0.0 \pm 0.0$ & $100.0 \pm 0.0$ & $70.83 \pm 29.17$ & $32.2 \pm 1.4$ \\
\hline
\end{tabular}

a Symbols: $-=$ not tested and NS = no symptoms.

b Shoots of Pyrus pyrifolia 'Hohsui' were used in this test. Values were means ( \pm standard error [SE]) of two repeated experiments. Data were calculated using disease incidence of 16 to 20 inoculation sites on shoots of intact plants or detached shoots.

${ }^{c}$ Fruit of $P$. bretschneideri 'Huangguan' were used in this test. Values were means $( \pm \mathrm{SE})$ of two repeated experiments at 4 days post inoculation. Data was calculated using lesion diameters of nine inoculation sites.

d Symptom descriptions based on unwounded shoots from intact pear plants inoculated with isolates of Botryosphaeria spp. Inoculation with all isolates tested caused canker development on the wounded shoots, except LNT1111 that also resulted in ring rot symptoms at 40 days post inoculation.

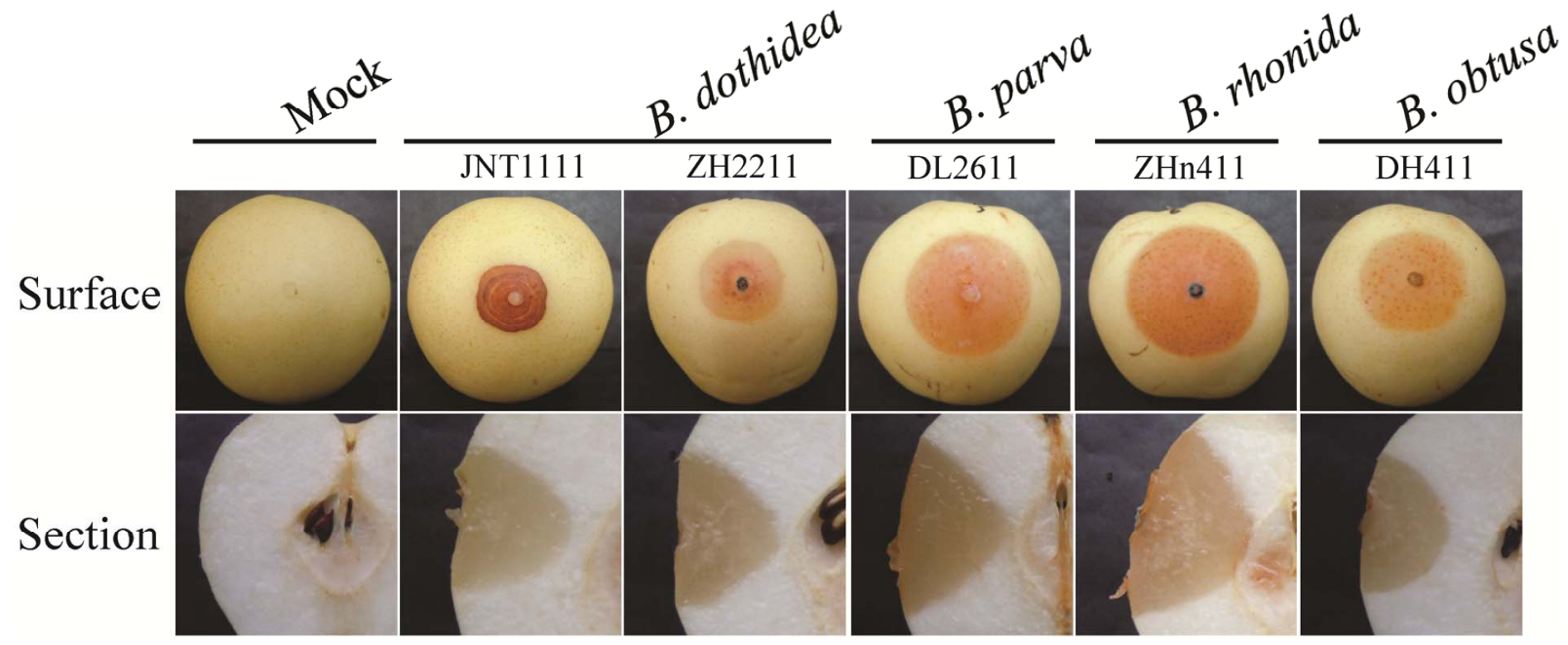

Fig. 8. Pear fruit (Pyrus bretschneideri 'Huangguan') were wounded, inoculated, and photographed at 4 days post inoculation. The bottom row shows cross-sections of the healthy and diseased fruit. From left to right: mock-inoculation and inoculations with Botryosphaeria dothidea (isolates JNT1111 and ZH2211), B. parva (isolate DL2611), B. rhodina (isolate ZHn411), and B. obtusa (isolate DH411). 
consistent with an early report that the stem wart and stem canker diseases of apple were mainly caused by B. dothidea in China (44). However, our study revealed three additional Botryosphaeria spp. (B. parva, B. rhodina, and B. obtusa) also responsible for causing stem canker diseases of pear. Pathogenicity tests demonstrated that isolates of $B$. parva, B. obtusa, and B. rhodina could cause stem canker symptoms on wounded shoots. However, isolates of $B$. rhodina and $B$. obtusa species were unable to cause any symptoms on the unwounded shoots, suggesting that the two species should act as opportunistic pathogens and infect only wounded pear tissues. Previous studies suggested that many members of the genus Botryosphaeria were generally considered to be weak or opportunistic pathogens as well as common endophytes of woody plants $(28,40)$. Interestingly, isolates of $B$. parva caused more severe diseases under all disease test conditions than that caused by isolates of $B$. dothidea, indicating that $B$. parva isolates were more virulent than $B$. dothidea isolates on host pear. Although most isolates of $B$. parva were obtained only from Sichuan and Yunnan provinces (one isolate from the Beijing region), both of which are located in southwestern China, this highly virulent species may be considered an emerging threat to pear growth in China. It has been suggested that the pathogenesis of Botryosphaeria spp. could be influenced by several environmental factors such as temperature, humidity, and wounding of the host plant (44). In other studies, these four species of the Botryosphaeria were also identified as casual agents responsible for diseases of many other host species in China $(18,47,49-52)$. Whether pear trees can be infected by the inoculums of these species from other hosts plants requires further investigation. This study showed that the geographical distribution of the Botryosphaeriaceae spp. from pear trees in China was considerably different among the provinces sampled, except for $B$. dothidea that predominantly appeared in all pear-growing regions in China. Possible environmental or ecological adaptation of Botryosphaeria spp. is worthy of further study.

The causal agent of the stem wart and stem canker diseases of apple was also identified as $B$. dothidea. Apple trees infected by $B$. dothidea normally formed the stem wart symptom under high humidity and produced stem canker symptoms under drought conditions (44). Our study revealed that pear stem wart usually occurred in the north and south of China, whereas pear stem canker appeared mainly in northern China. Moreover, it was found that the symptoms of both stem wart and stem canker could occur on the same pear tree and during the same time in the field. In addition, our results showed that $B$. dothidea could induce either stem wart or stem canker in the same experimental conditions, depending on the isolates used (Fig 6). This suggests that symptom development induced by $B$. dothidea infection is not only affected by environmental conditions but also depends on pathogen virulence. Nevertheless, isolates of $B$. parva, B. obtusa, and B. rhodina could only induce stem canker on shoots of pear. Furthermore, a study on the molecular and cellular interactions between Botryosphaeria spp. and their hosts will help to explore the possible mechanisms underlying the pathogenicity or virulence of $B$. dothidea and other species of this genus in pear.

\section{Acknowledgments}

This study was supported financially by the Chinese Ministry of Agriculture, Industry Technology Research Project (grant numbers 201203034-02 and 200903004-05) and the earmarked fund for Pear Modern Agro-industry Technology Research System (CARS-29-10). We thank Y. Wei, University of Saskatchewan, Canada, and G. Li, Huazhong Agricultural University, China, for critical revisions for the manuscript.

\section{Literature Cited}

1. Al-Haq, M. I., Seo, Y., Oshita, S., and Kawagoe, Y. 2002. Disinfection effects of electrolyzed oxidizing water on suppressing fruit rot of pear caused by Botryosphaeria berengeriana. Food. Res. Int. 35:657-664.

2. Alves, A., Phillips, A. J. L., Henriques, I., and Correia, I. A. 2007. Rapid differentiation of species of Botryosphaeriaceae by PCR finger printing. Res. Microbiol. 158:112-121.

3. Biggs, A. R., and Miller, S. S. 2004. Relative susceptibility of selected apple cultivars to fruit rot caused by Botryosphaeria obtusa. Hort-
Science 2:303-306.

4. Chen, C. 1999. Advances in the research of apple ring rot. Acta Phytopathol. Sin. 29:193-198. (In Chinese)

5. Crous, P. W., Phillips, A. J. L., and Baxter, A. P. 2000. Phytopathogenic fungi from South Africa. Department of Plant Pathology Press, University of Stellenbosch Printers, Stellenbosch, South Africa.

6. Crous, P. W., Slippers, B., Wingfield, M. J., Rheeder, J., Marasas, W. F. O., Phillips, A. J. L., Alves, A., Burgess T., Barber, P., and Groenewald, J. Z. 2006. Phylogenetic lineages in the Botryosphaeriaceae. Stud. Mycol. 55:239-257.

7. Denman, S., Crous, P. W., Taylor, J. E., Kang, J. C., Pascoe, I., and Wingfield, M. J. 2000. An overview of the taxonomic history of Botryosphaeria, and a re-evaluation of its anamorphs based on morphology and ITS rDNA phylogeny. Stud. Mycol. 45:129-140.

8. Drake, C. R. 1971. Source and longevity of apple fruit rot inoculum, Botryosphaeria ribis and physalospora obtusa, under orchard condition. Plant Dis. 55:122-126.

9. Gabr, M. R., Saleh, O. I., El-Hoda, A. H., and Shehata, Z. A. 1990. Botryodiplodia fruit rot of pear fruit, some physiological and pathological studies. Ann. Agric. Sci. (Cairo) 1:427-444.

10. Glass, N. L., and Donldson, G. C. 1995. Development of primer sets designed for use with the PCR to amplify conserved genes from filamentous ascomycetes. Appl. Environ. Microbiol. 61:1323-1330.

11. Guo, L. Y., Li, J. Y., Li, B. H., Zhang, X. Z., Zhou, Z. Q., and Li, G. X. 2009. Investigation on the occurrence and chemical control of Botryosphaeria canker of apple in China. Plant Prot. 35:120-123. (In Chinese)

12. Ignazio, C., and Linda, M. K. 1999. A method for designing primer sets for speciation studies in filamentous ascomycetes. Mycologia 91:553-556.

13. Jones, A. L., and Aldwinckle, H. S. 1990. Compendium of Apple and Pear Disease. American Phytopathological Society, St. Paul, MN.

14. Kim, K. W., Park, E. W., Kim, Y. H., Ahn, K. K., Kim, P. G., and Kim, K. S. 2001. Latency and defense-related ultrastructural characteristics of apple fruit tissues infected with Botryosphaeria dothidea. Phytopathology 91:165-172.

15. Koganezawa, H., and Sakuma, T. 1980. Fungi associated with blister canker and internal bark necrosis of apple trees. Bull. Fruit Tree Res. Stn. C (Morioka) 7:83-99.

16. Koganezawa, H., and Sakuma, T. 1984. Causal fungi of apple fruit rot. Bull. Fruit Tree Res. Stn. Jpn. Ser. C 11:63-73.

17. Lazzizera, C., Frisullo, S., Alves, A., and Phillips, A. J. L. 2008. Morphology, phylogeny and pathogenicity of Botryosphaeria and Neofusicoccum species associated with drupe rot of olives in southern Italy. Plant Pathol. 57:948-956.

18. Li, S. B., Li, J.Z., Li, S. C., Lu, Z. H., Wang, J. H., and Zhang, H. 2010. First report of Neofusicoccum parvum causing dieback disease of Chinese weeping cypress in China. Plant Dis. 94:641.

19. McDonald, V., Lynch, S., and Eskalen, A. 2009. First report of Neofusicoccum australe, $N$. luteum, and $N$. parvum associated with avocado branch canker in California. Plant Dis. 93:967.

20. Melzer, R. R., and Berton, O. 1988. Survey of wood attacking fungi in apple orchards of Santa Catarina state, Brazil. Acta Hortic. (ISHS) 232:219222.

21. Mohali S., Burgess T. I., and Wingfield M. J. 2005. Diversity and host association of the tropical tree endophyte Lasiodiplodia theobromae revealed using simple sequence repeat markers. For. Pathol. 35:385-396.

22. Molina-Gayosso E., Silva-Rojas H. V., García-Morales S., and Avila-Quezada G. 2012. First report of black spots on avocado fruit caused by Neofusicoccum parvum in Mexico. Plant Dis. 96:287.

23. Ni, H. F., Yang, H. R., Chen, R. S., Hung, T. H., and Liou, R, F. 2012. A nested multiplex PCR for species-specific identification and detection of Botryosphaeriaceae species on mango. Eur. J. Plant Pathol. 133:819-828.

24. Ogata, T., Sano, T., and Harada, Y. 2000. Botryosphaeria spp. isolated from apple and several deciduous fruit trees are divided into three groups based on the production of warts on twigs, size of conidia, and nucleotide sequences of nuclear ribosomal DNA ITS regions. Mycoscience 41:331-337.

25. Pavlic, D., Slippers, B., Coutinho, T. A., Gryenhout, M., and Wingfield, M. J. 2004. Lasiodiplodia gonubiensis sp. nov., a new Botryosphaeria anamorph from native Syzygium cordatum in South Africa. Stud. Mycol. 50:313-322.

26. Pavlic, D., Wingfield, M. J., Barber, P., Slippers, B., Hardy G. E. St. J., and Burgess, T. I. 2008. Seven new species of the Botryosphaeriaceae from baobab and other native trees in Western Australia. Mycologia 100:851-866.

27. Pennycook, S. R., and Samuels, G. J. 1985. Botryosphaeria and Fusicoccum species associated with ripe fruit rot of Actinidia deliciosa (kiwifruit) in New Zealand. Mycotaxon 24:445-458.

28. Pérez, C. A., Wingfield, M. J., Slippers, B., Altier, N. A., and Blanchette, R. A. 2010. Endophytic and canker-associated Botryosphaeriaceae occurring on non-native Eucalyptus and native Myrtaceae trees in Uruguay. Fungal Divers. 41:53-69.29.

29. Phillips, A. J. L., Alves, A., Correia, A., and Luque, J. 2005. Two new species of Botryosphaeria with brown, 1-septate ascospores and Dothiorella anamorphs. Mycologia 97:513-529.

30. Phillips, A. J. L., Crous, P. W., and Alves, A. 2007. Diplodia seriata, the anamorph of "Botryosphaeria" obtusa. Fungal Divers. 25:141-155. 
31. Phillips, A. J. L., Oudemans, P. V., Correia, A., and Alves, A. 2006. Characterisation and epitypification of Botryosphaeria cortices, the cause of blueberry cane canker. Fungal Divers. 21:141-155.

32. Phillips, A. J. L., Rumbos, I. C., Alves, A., and Correia, A. 2005. Morphology and phylogeny of Botryosphaeria dothidea causing fruit rot of olives. Mycopathologia 159:433-439.

33. Sambrook, J., and Russell, D. W. 2001. Molecular Cloning: A Laboratory Manual. Cold Spring Harbor Laboratory Press, Cold Spring Harbor, NY.

34. Shah, M. D., Verma, K. S., Singh, K., and Kaur, R. 2010. Morphological, pathological and molecular variability in Botryodiplodia theobromae (Botryosphaeriaceae) isolates associated with die-back and bark canker of pear trees in Punjab, India. Genet. Mol. Res. 2:1217-1228.

35. Shah, M. D., Verma, K. S., Singh, K., Kaur, R. 2011. Genetic diversity and gene flow estimates among three populations of Botryodiplodia theobromae causing die-back and bark canker of pear in Punjab. Arch. Phytopathol. Plant Prot. 10:951-960.

36. Shen, Y. M., Chao, C. H., and Liu, H. L. 2010. First report of Neofusicoccum parvum associated with stem canker and dieback of Asian pear trees in Taiwan. Plant Dis. 94:1062.

37. Slippers, B., Burgess, T., Wingfield, B. D., Crous, P. W., Coutinho, T. A., and Wingfield, M. J. 2004. Development of simple sequence repeat markers for Botryosphaeria spp. with Fusicoccum anamorphs. Mol. Ecol. Notes 4:675-677.

38. Slippers, B., Crous, P. W., Denman, S., Coutinho, T. A., Wingfield, B. D., and Wingfield, M. J. 2004. Combined multiple gene genealogies and phenotypic characters differentiate several species previously identified as Botryosphaeria dothidea. Mycologia 96:83-101.

39. Slippers, B., Smit, W. A., Crous, P. W., Coutinho, T. A., Wingfield, B. D., and Wingfield, M. J. 2007. Taxonomy, phylogeny and identification of Botryosphaeriaceae associated with pome and stone fruit trees in South Africa and other regions of the world. Plant Pathol. 56:128-139.

40. Slippers, B., and Wingfield, M. J. 2007. Botryosphaeriaceae as endophytes and latent pathogens of woody plants: diversity, ecology and impact. Fungal Biol. Rev. 21:90-106.

41. Smith, B. J. 2009. Botryosphaeria Stem blight of southern blueberries: cultivar susceptibility and effect of chemical treatments. Acta Hortic. 810:385-394.

42. Smith, D. R., Michailides, T. J., and Stanosz, G. R. 2009. Differentiation of a Fusicoccum sp. causing panicle and shoot blight on California pistachio trees from Botryosphaeria dothidea. Plant Dis. 85:1235-1240.

43. Smith, H., Kemp, G. H. J., and Wingfield, M. J. 1994. Canker and die-back of Eucalyptus in South Africa caused by Botryosphaeria dothidea. Plant Pathol. 43:10-14.

44. Tang, W., Ding, Z., Zhou, Z. Q., Wang, Y. Z., and Guo, L. Y. 2012. Phylogenetic and pathogenic analyses show that the causal agent of apple ring rot in China is Botryosphaeria dothidea. Plant Dis. 96:486-496.

45. Thomidis, T., Michailides, T. J., and Exadaktylou E. 2011. Neofusicoccum parvum associated with fruit rot and shoot blight of peaches in Greece. Eur. J. Plant Pathol. 131:661-668.

46. van Niekerk, J. M., Crous, P. W., Groenewald, J. Z., Fourie, P. H., and Halleen, F. 2004. DNA phylogeny, morphology and pathogenicity of Botryosphaeria species on grapevines. Mycologia 4:781-798.

47. Wang, F., Zhao L. N., Li, G. H., Huang J. B., and Hsiang, T. 2011. Identification and characterization of Botryosphaeria spp. causing gummosis of peach trees in Hubei Province, central China. Plant Dis. 95:1378-1384.

48. White, T. J., Bruns, T., Lee, S., and Taylor, J. 1990. Amplification and direct sequencing of fungal ribosomal RNA genes for phylogenetics. Pages 315-322 in: PCR Procotols: A Guide to Methods and Applications. M. A. Innis, D. H. Gelfand, J. J. Sninsky, and T. J. White, eds. Academic Press, New York.

49. Yan, J. Y., Peng, Y. L., Xie, Y., Li, X. H., Yao, S. W., Tang, M. L., and Wang, Z. Y. 2011. First report of grapevine trunk disease caused by Botryosphaeria obtusa in China. Plant Dis. 95:616.

50. Yan, J. Y., Xie, Y., Yao, S. W., Wang, Z. Y., and Li, X. H. 2012. Characterization of Botryosphaeria dothidea, the causal agent of grapevine canker in China. Australas. Plant Pathol. 41:351-357.

51. Yan, J. Y., Xie, Y., Zhang, W., Wang Y., Liu J. K., Hyde, K. D., Seem, R. C., Zhang, G. Z., Wang, Z. Y., Yao, S. W., Bai X. J., Dissanayake, A. J., Peng, Y. L., and Li X. H. 2013. Species of Botryosphaeriaceae involved in grapevine dieback in China. Fungal Divers. 61:221-236.

52. Yu, L., Impaprasert, R., Zhao, J. R., Xu, S. G., and Wu, X. 2013. Stem dieback of high bush blueberries caused by Neofusicoccum parvum in China. New Dis. Rep. J. 27:3.

53. Zea-Bonilla T., González-Sánchez M. A., Martín-Sánchez P. M., and PérezJiménez R. M. 2007. Avocado dieback caused by Neofusicoccum parvum in the Andalucia Region, Spain. Plant Dis. 91:1052.

54. Zhou, S., Smith, D. R., and Stanosz, G. R. 2001. Differentiation of Botry osphaeria species and related anamorphic fungi using inter simple or short sequence repeat (ISSR) fingerprinting. Mycol. Res. 105:919-926. 